\section{Dubinina M., Cheban Y., Horbach 5 ., Dubinin V.}

\title{
IMPROVEMENT OF ORGANIZATIONAL AND DOCUMENTARY SECURITY OF VACATION
}

\begin{abstract}
Проведено аналіз основних історичних передумов та етапів розвитку нормативного регулювання надання відпустки. Досліджено основні особливості надання відпустки у сільськогосподарських підприємствах Миколаївської області (Україна). Визначено загальні елементи складових та характеристик поняття «відпустка». Накреслено основні напрями удосконалення організаційно-документального забезпечення відпустки та ї̈ використання у контексті сочіальної діяльності підприємств.
\end{abstract}

Ключові слова: регулювання надання відпустки, нормативне забезпечення, внутрішній документ, колективний договір, фінансова звітність.

\section{Introduction}

In modern conditions of management of agrarian enterprises, a special urgency is acquired by the study of social and labor relations, which are one of the components of the development of the market economy and the welfare of the population. Work must necessarily alternate with rest. That is why the legislation of Ukraine gives considerable attention to the settlement of the realization issue of the human right to rest. The right to vacation is part of the legal status of the employee. It has every employee who works under an employment contract. At the same time, the right to vacation is fixed by international legal acts and the provision of the employee's right to receive vacation is guaranteed by the state. At the same time, the term «vacation» is a significant circle of various phenomena that have specific features in various branches of the economy, including agrarian space, in different regions, different production conditions, and the like. The aforementioned complicates not only the basic definition of the term «vacation», but also its organizational and accounting support. The relevance of the selected site of the study becomes important in the context of the absence of any statistical data on species and the volume of vacations, as well as the lack of information in the forms of financial and statistical reporting.

The issue of organizing, documenting, recording and controlling vacations is one of the directions for scientific research of a significant circle of scientists, but only in a complex of research on labor and its payment. That is, the economic object chosen for research is being studied today either purely from the legal point of view or as a component of payments to employees. The autonomous study of vacation dates only to the works of 1980-1990. Changes in the regulatory framework, the impact of external and internal factors on the conditions of business management, the prospects for their integrated development require the study of the organization, provision, internal documentary release of the vacation at the present stage.

\section{The object of research and its technological audit}

The object of the study is a system of organizational and documentary support for the design and provision of vacations in agricultural enterprises.

The peculiarities of normative and organizational regulation of labor have always been related to the features of rest regulation. These questions also appeared in ancient countries. So, in ancient Rome, there was not only a vacation, but also the first resorts for the «vacation». But such pleasure was received only by wealthy citizens. However, even slaves had their «vacations», which lasted a week. Workers of factories and manufactories in the Middle Ages did not even have a single week of rest. Weekends were religious holidays and Sundays. The work was not at all, or it was very little, in the cold season. Such days were the so-called «vacation without pay». In the XIX century, European public servants and teachers were already on vacation. However, the size of the «vacation» was not settled and the workers either did not receive anything at all, or were satisfied with a small reward. The first paid vacation was given to officials only in the time of Napoleon. In the end of the 15th century, with the development of manufactory production, the first cases of work on Sunday arise and the desire of employers to reduce the number In this period, more attention is paid to determining the number of days off in a year, not weekly rest. At the turn of the 18th and 19th centuries, work at factories in and religious holidays became the rule. One of the first acts legalized weekly rests on Sunday was the French Law of November 18, 1814. During the nineteenth century, such acts were adopted in most Western countries. The attraction to wage labor of a large number of women exacerbated the problem of their release from First, in the legislation of many countries, this vacation was called «rest after childbirth», which lasted 3-4 weeks and was paid, as a rule, in part. Provision of paid vacations in the early twentieth century was regulated only in a collectivecontractual and individually-contractual manner. 
So, historical experience is often interesting, always almost valuable. Useful for improving the organizational and accounting provision of vacation is the experience of other countries, reviewed and transformed to implementation at Ukrainian enterprises below. At the same time, this experience is based directly on the features of giving vacations to these countries. Thus, in the UK, the minimum annual vacation is approved in the amount of 28 working days and 8 national paid holidays; in Israel, the minimum annual vacation is 12 working days. Germany has the minimum annual vacation - 20 working days [1]. France is characterized by a normative fixation, not the minimum, but the maximum annual vacation in 30 working days (2.5 days for each month of continuous work) [2]. There is also a differentiation of vacation periods for enterprises of different industries. In the United States there is no concept of the approved minimum annual vacation. There is «time off», the number of which depends on the length of service (1-2 years - 6 days, more than 5 years $-15-17$ days). $13 \%$ of time off does not pay [3].

One of the most problematic places is a significant variety of definitions and components of the concept of vacations. Insufficient reflection in the scientific literature of the classification of vacations. Absence of a convincing theoretical and methodological base for research of the peculiarities of granting vacations in agricultural enterprises.

\section{The aim and objectives of research}

The aim of research is analysis of the regulatory and organizational features of granting a vacation in the context of historical and modern business conditions and transforming its results for introduction into the activities of today's enterprises.

To achieve this aim, the following tasks are identified:

1. To analyze the main historical prerequisites and stages in the development of regulatory regulation of vacation.

2. To investigate the main components and characteristics of «vacation» concept and determine their generalized elements.

3. To analyze the main features of the granting of vacations in agricultural enterprises of the Mykolaiv region (Ukraine).

4. To develop the main directions for improving the organizational and documentary support for vacation and its use in the context of the social activities of enterprises.

\section{Research of existing solutions of the problem}

The issue of organizing, documenting, recording and controlling vacations is one of the directions for scientific research of a significant number of scientists, but only in a complex of research on labor and its payment. That is, the economic object chosen for research is studied today, for example, either purely from the legal side [4-8], or as a component of payments to employees [9-13]. Autonomous research of vacation dates only to the works of 1980-1990 and even earlier [14-19].

Thus, in the first half of the 17th century, the problem of the ratio of daily working time to rest time was first studied. The theory of «three eights» was developed, ac- cording to which for an eight-hour working day 16 hours were necessary for rest, including 8 - for sleep [20].

According to the carried out studies, the definition of the «vacation» term, its separate types and classifications are different according to the approaches and interpretation of the researchers of this issue [21]. Not all of them are fixed in the current legislation. The following characteristics of vacation as a general concept are defined: temporary exemption from the employee's performance of his labor duties; a certain period of calendar time; preservation for the employee or employees of the place of work and wages; use of vacation for a specific purpose [17]. The «vacation» term is broadly interpreted as exemption from work, from the grounds provided for by law for a certain number of days, with the preservation of the place of work or position, that is, exemption from the performance of labor duties in accordance with the rules of internal labor regulations [18]. Other researchers treat vacation as the release of an employee from work to rest for a certain number of working days per year, while retaining wages for these days [19].

The views of scientists differ somewhat in the interpretation of the vacation content because of the lack of its official definition in regulatory sources. Classification is one of the research areas of all scientists and is of great importance for statistics, accounting, analysis and control, as it provides more detailed information about the facility. Classification with time is being improved, so let's give examples of its development on the research topic. Thus, the legislation of the Ukrainian SSR (in 1922). The following types of vacations were fixed: regular and additional. At the same time, in the scientific literature [22], the following types of vacations are singled out:

- labor;

- in connection with temporary incapacity for work (in case of illness, injury, in connection with pregnancy and childbirth, vacation to care for a sick family member, for sanatorium treatment);

- in connection with training; creative vacations.

In modern Ukraine there are legislatively regulated there are such kinds of vacations as [23]:

1) annual vacation (basic vacation, additional vacation for work with harmful and difficult working conditions, additional vacation for special nature of work, other additional vacations provided for by law);

2) additional vacation in connection with training;

3) creative vacation (vacation for preparation and participation in competitions, completion of dissertation research, etc.);

4) social vacations:

- vacation in connection with pregnancy and childbirth;

- vacation to take care of a child before reaching the age of three;

- vacation in connection with the adoption of a child; - additional vacation for workers who have children or an adult child - disabled person from the childhood of subgroup A of group I and others);

$5)$ vacation without pay.

Thus, changes in the regulatory framework, the impact of external and internal factors on the conditions for managing enterprises, the prospects for their integrated development require research on the organization, provision, accounting and control of vacation at the present stage. 


\section{Methods of research}

Theoretical and methodological basis of the research are: - basic provisions of economic theory, industry economics, marketing, management;

- scientific developments and publications on regulatory support, granting, registration and control of vacation;

- legislative and regulatory acts governing the object of research.

In the process of research, a wide range of economic methods were used, including: historical (in studying the trends in the formation of legislation on vacations). Method of the system approach (in studying the connections between phenomena and processes of economic reality). Abstractlogical method (in determining and clarifying the basic concepts and components of the vacation). Monographic method (when investigating the best practices of individual farms). Economic-statistical method (when processing official statistics of different levels); sociological (for the collection of factual material through observation using questionnaires). The information base of the study was:

- organizational and accounting data of the investi-

gated enterprises;

- scientific and analytical publications;

- the results of personal observations;

- questioning;

- authors' calculations.

\section{Research results}

Vacation is always a concept of a legal basis. Therefore, the main stages of the development of legislation on vacations (Table 1) are investigated.

Each stage is characterized by the improvement of legislation on vacations and the introduction of new types of additional vacation. The replacement of the vacation with monetary compensation negatively affected the health of workers and labor productivity, so it is still prohibited in the current legislation. Legal regulation of vacations during the first stages developed mainly through the establishment of special norms, only extended to certain categories of workers and had a narrow scope. In accordance with the provisions of the Law of Ukraine «On vacations», citizens of Ukraine who are in labor relations with enterprises have the right to vacation, and they also work under an employment contract with an individual [23]. To acquire the right to vacation the employee must be in labor relations with the enterprise or conclude an employment contract with an individual. According to the current legislation, foreign citizens and stateless persons working in Ukraine have the right to vacation on an equal basis with citizens of Ukraine.

The analysis of the regulatory and legal framework and scientific research on the organization and recording of vacations makes it possible to significantly expand the «vacation» concept. So, vacation is determined by:

- an independent kind of time for rest, provides for

a wide differentiation;

- free time from work, during which the employee retains his place of work and position;

- rest for several days in a row with the preservation of the place of work and average earnings;

- release of the employee from the performance of official duties with the preservation of the place of work and average earnings;

- continuous free time from work, during which the employee retains his place of work (position) and average earnings;

- a period of time that is provided for a long rest of an employee, the restoration of physical and mental health, the implementation of socio-cultural needs of a person (travel, communication with the family, etc.); - a certain number of days off from work, which is provided to the employee for continuous rest and restoration of working capacity with preservation of the place of work and average earnings.

The generalized definition of vacation is complicated by its indisputable legal basis and simultaneous regulation by the norms of international labor law. At the same time, some kinds of vacations are not regulated by the legislation and should be covered in the internal documentation of the enterprise.

The main stages of the development of legislation on vacations

\begin{tabular}{|c|c|c|c|}
\hline Stage & Years & Normative document & Peculiarities \\
\hline I & 1917-1921 & Dесгеe «Dn vacations» & $\begin{array}{l}\text { The procedure for granting vacation and its duration is reflected (subject to work for at least } \\
6 \text { months, a two-week vacation is granted) }\end{array}$ \\
\hline II & 1922-1941 & $\begin{array}{l}\text { Regulations on regular and addi- } \\
\text { tional vacations Labor Code of } 1922\end{array}$ & $\begin{array}{l}\text { A separate section "Time of rest» is highlighted. Reflected the granting to women of vacation } \\
\text { of } 56 \text { calendar days before the birth and } 56 \text { calendar days after the birth. Extra vacation is } \\
\text { provided for employees engaged in harmful work and with a non-standard working day and } \\
\text { persons who have a long working record at one enterprise }\end{array}$ \\
\hline III & 1941-1945 & $\begin{array}{l}\text { Regulations on regular and addi- } \\
\text { tional vacations Labor Code of } 1922\end{array}$ & $\begin{array}{l}\text { Contained reduction of individual guarantees, which were of a temporary nature for military } \\
\text { operations }\end{array}$ \\
\hline IV & 1946-1970 & Labor Code of 1922 & $\begin{array}{l}\text { Added educational and creative vacations. Particular attention is paid to educational vacations } \\
\text { for the successful combination of study and work. Allowed payment of cash compensation for } \\
\text { unused vacation }\end{array}$ \\
\hline V & 1971-1991 & $\begin{array}{l}\text { Fundamentals of labor legislation. } \\
\text { The Labor Code of the Ukrainian SSR }\end{array}$ & $\begin{array}{l}\text { The range of annual additional vacations has been expanded, in particular vacation for work } \\
\text { in the conditions of the Far North, public educators of minors and others was added. The ban } \\
\text { was introduced to replace the annual vacation with monetary compensation, except for cases } \\
\text { of dismissal of workers, did not use vacation }\end{array}$ \\
\hline VI & 1991-now & The Law of Ukraine «On vacations» & $\begin{array}{l}\text { Formation of its own regulatory framework, types of vacations, conditions for their provision, } \\
\text { documentation }\end{array}$ \\
\hline
\end{tabular}

Note: is formed by the authors on the basis of $[8,20,22]$. 
At the same time, the most common vacations are those that have a labor basis, that is, they are regulated by the rules of labor law, and are provided on the basis of the Ukrainian labor legislation. That is why the main features that are inherent in the overwhelming majority of vacations are highlighted: the release of the employee from the performance of labor duties, the retention of employment (position), payment of the employee in the vacation period.

It is also possible to note that Ukrainian legislation, along with the scientific achievements of researchers, the term «vacation» is identified with the concept of «time». So, according to studies, this is a period of time; time interval; number of days; number of calendar days; number of working days; a certain number of days; continuous rest time; number of days and the like.

So, in the definitions and characteristics of the «vacation» concept, as a rule, the main distinctive and characteristic features are noted. Let's refer to them:

- guarantee of granting vacation by the legislation;

- the scope of the vacations;

- periodicity of granting of vacations;

- determination of the vacation duration in the legis-

lation;

- continuity of rest during the vacation;

- connection of vacation with work experience;

- the main purpose of vacation;

- preservation of the place of work for the vacation period;

- preservation of the average salary for the vacation period;

- vacation payment.

From the existing types of vacations, a group of social vacations is quite interesting, primarily because of the lack of legislative and regulatory regulation of a certain part of them. So, for example, some types of social vacations are established at enterprises within their social policy and social responsibility - vacation for the occasion of the jubilee, vacation for winning competitions and the like. Such types of vacation are not reflected in the legislation. Their form, duration, payment is determined by the work collective and regulated by the provisions of internal administrative documents, in particular in the collective agreement. According to the research, the duration of such vacations is from one to three working days.

To study the state of the organization, documenting and registering vacations at agricultural enterprises in the Mykolaiv region (Ukraine), a questionnaire survey of managers and chief accountants of 50 enterprises from 12 districts of the region was carried out. Among the respondents - 15 farms, 10 private enterprises, 20 limited liability companies, 4 private joint-stock companies, 1 public joint-stock company.

The main types of vacations given to employees of these enterprises for the period 2014-2016 are shown in Table 2.

So, according to the current legislation, at all enterprises, regardless of the form of management and ownership, basic vacation was granted to employees, in $22 \%$ - additional paid vacation in connection with training. Additional vacation for mothers who had two or more children under 15 years of age were taken advantage of by workers of $58 \%$ of the enterprises surveyed. The confirmation of the social policy of enterprises is the provision of various types of vacation without pay for personal and other reasons.

In all of the surveyed enterprises, the granting of vacation is reflected in the order for granting vacation on the basis of the relevant application of the employee. The order specifies the surname of the employee who goes on vacation, the profession, the type of vacation and the period for which the given vacation is granted.

Table 2

Types of vacations granted to employees of agricultural enterprises of Mykolaiv region for 2014-2016

\begin{tabular}{|c|c|c|}
\hline \multirow[b]{2}{*}{ Types of vacations } & \multicolumn{2}{|c|}{ Respondents } \\
\hline & $\begin{array}{l}\text { Number of } \\
\text { enterprises, } \\
\text { items }\end{array}$ & $\begin{array}{l}\text { Share in the } \\
\text { total number of } \\
\text { respondents, \% }\end{array}$ \\
\hline Basic vacation & 50 & 100.0 \\
\hline Additional vacation due to education & 11 & 22.0 \\
\hline $\begin{array}{l}\text { Social vacation, including: } \\
\text { vacation for pregnancy and childbirth } \\
\text { vacation to care for a child until he } \\
\text { reaches the age of three } \\
\text { a mother who has two or more children } \\
\text { under the age of } 15\end{array}$ & $\begin{array}{l}15 \\
29\end{array}$ & $\begin{array}{l}38.0 \\
30.0 \\
58.0\end{array}$ \\
\hline $\begin{array}{l}\text { Vacation without pay, including: } \\
\text { in connection with the birth of a child } \\
\text { (grandchildren) } \\
\text { in connection with marriage } \\
\text { for sanitation and spa treatment } \\
\text { by agreement of the parties } \\
\text { in connection with the death of relatives }\end{array}$ & $\begin{array}{c}47 \\
10 \\
3 \\
1 \\
16 \\
31\end{array}$ & $\begin{array}{c}94.0 \\
20.0 \\
6.0 \\
2.0 \\
32.0 \\
62.0\end{array}$ \\
\hline
\end{tabular}

It should be noted that proper accounting of personnel plays an important role in the correct calculation of vacation payroll, which accounts for $58 \%$ of enterprises. Despite the scheduling of vacations, the reserve for vacation pay is formed only at 9 enterprises.

Let's note that there is no form of financial and statistical reporting containing a separate article to reflect the amounts of paid vacation (Table 3 ).

Thus, the type of employee benefits in all forms is included in one or another article, where it is reflected together with other payments. The latter creates difficulties in the analysis and planning of vacations, especially if the enterprise uses various types of social vacations. It is also established that there is no information on the volume of vacation and types of vacation in the official statistical information of the State Statistics Service of Ukraine, which is made public.

It is established that the social policy of the enterprise, including the system of granting vacations, occupies a special place in the formation of motivation of employees, increase of their self-expression in the work. The interest of employees in the work at the enterprise and its successful economic activity directly depends on how much the payment exceeds the statutory amount. Such policy can ensure the existence of workers in the case of a low level of wages (as observed in most agricultural enterprises) or offered in the interests of attracting and retaining a skilled workforce. The latter is quite relevant provided that workers are recruited into the countryside.

In modern conditions, as practice shows, it is completely inadequate to use incentives to work only to meet nutritional, housing and clothing needs. When the employee reaches a certain professional level, the satisfaction of these needs becomes routine and insignificant. The social relations connected with the labor activity of the individual come to the fore. One of such unused social benefits is 
the provision of additional social vacations, which are not only and not always an additional material incentive, but a solution to a significant range of social issues and problems of employees as individuals, members of their families, members of the enterprise collective.

According to research, the management of agricultural enterprises uses material and non-material motivation.

So, among the material incentive methods the most common are those that are related to wages (salary increases, bonuses, bonuses, loans, etc.). Among the nonmaterial, there are gifts for vacations and birthdays, corporate holidays, training and courses. Let's note that only $5 \%$ of respondents (surveyed 50 agricultural enterprises) use vacation as one of the methods of motivation.

So, there are cases of granting additional vacation without payment, additional vacation for family reasons, social vacation. At one of the respondent enterprises, vacation is given for treatment in sanatoriums without payment of the vacation period, but with payment of travel to the place of treatment and in the opposite direction.

Examples of the use of vacation as a method of motivation of labor in foreign countries are interesting and useful. They can be used in Ukrainian enterprises (Table 4).

So, the proposed directions for using additional social vacations are aimed at achieving certain social goals and development strategies for the enterprise (Table 5).

Let's note that the system of social motivation of employees through the provision of additional social vacations evolves along with changes in the economy of the state under the influence of external and internal factors, as well as significant features, management of agricultural enterprises.

Vacation in the forms of financial, statistical and tax reporting of the enterprises

\begin{tabular}{|c|c|}
\hline Keporting form & Article \\
\hline \multirow{2}{*}{$\begin{array}{l}\text { Form of financial statements No. } 1 \text { «Balance sheet } \\
\text { (Statement of financial position)» }\end{array}$} & Section II «Long-term liabilities, dedicated financing and collateral» \\
\hline & Section III article «Current payables for payroll calculations» (code 1630) \\
\hline \multirow{2}{*}{ Form of financial statements No.1-m «Balance» } & Section II «Long-term liabilities, dedicated financing and collateral» (code 1595) \\
\hline & Section III article «Current payables for payroll calculations» (code 1630) \\
\hline \multirow{2}{*}{$\begin{array}{l}\text { Form of financial statements No. } 2 \text { «Statement of fi- } \\
\text { nancial results (Statement of Comprehensive Income)» }\end{array}$} & $\begin{array}{l}\text { Section And the article «Cost of goods sold (goods, works, services)» (code 2050), item «Administrative } \\
\text { expenses» (code 2130), item "Sales costs» (code 2150), item «Dther operating expenses» (code } 2180 \text { ) }\end{array}$ \\
\hline & Section III article «Labor costs» (code 2505) \\
\hline \multirow{2}{*}{$\begin{array}{l}\text { Form of financial statements No.2-m «Statement of } \\
\text { financial results» }\end{array}$} & Article "Cost of sales (goods, works, services)» (code 2050) \\
\hline & Article 2180 «Dther operating expenses» \\
\hline $\begin{array}{l}\text { The form of statistical reporting No. 50-a.e. «Report on } \\
\text { the main economic indicators of agricultural enterprises» }\end{array}$ & Section II article «Labor costs» (code 0280) \\
\hline $\begin{array}{l}\text { Form of statistical reporting No. 2m-farm «heport on } \\
\text { costs for the production of agricultural products (works, } \\
\text { services)» }\end{array}$ & Section I, article «Direct labor costs» (code 2011) \\
\hline $\begin{array}{l}\text { Reporting form No. } 1 \mathrm{DF} \text { «Tax calculation of the amounts } \\
\text { of income accrued (paid) in favor of individuals and } \\
\text { amounts of tax withheld from them» }\end{array}$ & $\begin{array}{l}\text { Section I, article "The amount of income accrued (paid) in favor of individuals and the amount of } \\
\text { tax withheld from them» (code } 101 \text { in the context of individuals) }\end{array}$ \\
\hline
\end{tabular}

Table 4

Directions for the introduction of international experience in the use of vacation as one of the methods for motivating employees

\begin{tabular}{|c|c|c|}
\hline Country & The use of vacation as one of the methods of motivating employees & $\begin{array}{l}\text { The peculiarity of introduction to the } \\
\text { activities of Ukrainian enterprises }\end{array}$ \\
\hline United Kingdom & Additional vacation from 8 weeks to 6 months of continuing education, of which 2 months are paid & \multirow{5}{*}{$\begin{array}{l}\text { Instructions in the collective agreement } \\
\text { in the context of types of vacations } \\
\text { with mandatory documentary registra- } \\
\text { tion. Based on the application of the } \\
\text { employee with the attached document, } \\
\text { which is the basis for granting vacation. } \\
\text { For example, a marriage certificate; the } \\
\text { order of the head with reference to } \\
\text { the clause of the collective agreement; } \\
\text { calculation of payment for vacation; } \\
\text { payment document release etc. }\end{array}$} \\
\hline Israel & «Wellness» - annually 2 additional working days with the achievement of 5 years of experience & \\
\hline Germany & At will one of the parents of a child under 10 years of age is granted vacation during school holidays & \\
\hline France & $\begin{array}{l}\text { Spouses who work in the company have the right to go on vacation together } \\
\text { Postponement of the date of vacation by the administration of the enterprise for production reasons } \\
\text { is the basis for providing additional paid vacation for } 1-2 \text { days }\end{array}$ & \\
\hline USA & $\begin{array}{l}\text { Additional vacation for those who do not smoke } \\
\text { Long vacation (from } 13 \text { weeks to } 11 \text { months) for highly skilled workers who have a considerable } \\
\text { work experience in the enterprise }\end{array}$ & \\
\hline \multicolumn{3}{|c|}{ Also proposed for use in Ukraine } \\
\hline \multicolumn{3}{|c|}{$\begin{array}{l}\text { - additional paid vacation of } 2-5 \text { days as a reward to the employee, in addition to performing professional duties, received additional qualifications, intern- } \\
\text { ships, courses, trainings, etc.; } \\
\text { - additional paid vacation for } 1-2 \text { days for the organization of social events (sports days, charity events at the village, city, region, etc.) }\end{array}$} \\
\hline
\end{tabular}

Note: formed on the basis of $[1,2]$ and the results of their own research. 
The result of using vacation as motivation for employees

\begin{tabular}{|l|l|}
\hline \multicolumn{2}{|c|}{ The use of vacation as motivation for employees } \\
\hline \multicolumn{1}{|c|}{ Result } & \multicolumn{1}{|c|}{ Effect } \\
\hline $\begin{array}{l}\text { Performing not only work on job duties, } \\
\text { but also part-time jobs on interests and } \\
\text { vocational training }\end{array}$ & $\begin{array}{l}\text { Creative atmosphere, allows } \\
\text { for self-expression in work }\end{array}$ \\
\hline $\begin{array}{l}\text { Professional growth of an employee as } \\
\text { a specialist }\end{array}$ & $\begin{array}{l}\text { Increase of democratic leader- } \\
\text { ship and development of wor- } \\
\text { kers' initiative }\end{array}$ \\
\hline $\begin{array}{l}\text { Development of the employee as an individual } \\
\text { and the possibility of obtaining additional } \\
\text { income outside the enterprise }\end{array}$ & $\begin{array}{l}\text { A sense of confidence in the } \\
\text { future }\end{array}$ \\
\hline $\begin{array}{l}\text { Preserving and maintaining the health of } \\
\text { employees }\end{array}$ & $\begin{array}{l}\text { Increasing the efficiency of } \\
\text { staff utilization }\end{array}$ \\
\hline $\begin{array}{l}\text { Creating a favorable social and psychological } \\
\text { climate in the team }\end{array}$ & $\begin{array}{l}\text { Achieving the correspondence } \\
\text { of the goals of employees with } \\
\text { the overall objectives of the } \\
\text { enterprise and supporting the } \\
\text { team in implementing enter- } \\
\text { prise development programs }\end{array}$ \\
\hline
\end{tabular}

Studying the main features of the concept of «vacation», characteristic features, types and regulatory regulation, the main classification characteristics and types of vacations are determined (Table 6).

The proposed classification will allow for more detailed organization, documentation, accounting and control of accrual, use, payment, analysis and planning of vacations.

Let's note also that the vacations should be provided and paid on the basis of certain principles: legality, regulatory regulation, documenting, payment. Given the significant development of social responsibility of enterprises in recent years, vacation is one of the motivational factors of employees, has a direct impact on the performance of any enterprise. It is advisable to take this opportunity into account when developing the social policy of an enterprise and fixing it in the Collective Agreement.

Being in social and labor relations with the enterprise, the employee needs social protection, provision of which will ensure the observance of his rights, will provide an opportunity to effectively meet the needs of this employee and his family. And it will also contribute to the quantitative and qualitative recovery of the productive forces of society, in particular, of labor resources. The instrument of regulation of social and labor relations, which promotes maximum observance of the rights of wage workers and is coordinated with the positions of employers, is a collective agreement.

Information about the possible types of vacation with a list of mandatory documents should take place in the collective agreement and the employees of the enterprise must own it.

It is revealed that a small part of the surveyed respondents paid due attention to the creation of reserves for vacation pay. It should be noted that the vacation reserve is created in the accounting records with a view to uniformly allocating expenses for the payment of the time spent by employees on vacation between the reporting periods. The reserve of vacations should be created to pay annual (basic and additional) vacation, as well as additional vacations for workers with children. For other types of vacations (educational, creative vacation, vacation for participation in competitions, etc.), the reserve does not create.
Classification of vacations

\begin{tabular}{|c|c|}
\hline Classification feature & Types of vacations \\
\hline \multirow{2}{*}{$\begin{array}{l}\text { Source of legal } \\
\text { regulation }\end{array}$} & Regulated by international or Ukrainian law \\
\hline & Regulated by legal industry regulations \\
\hline \multirow{5}{*}{$\begin{array}{l}\text { Source of legal } \\
\text { regulation }\end{array}$} & Regulated by international instruments \\
\hline & Regulated by the current legislation \\
\hline & Regulated by social and partnership relations \\
\hline & Regulated by collective agreements \\
\hline & Regulated by an employment contract, a contract \\
\hline \multirow{2}{*}{ Aim } & For relax \\
\hline & To perform a specific task \\
\hline \multirow{2}{*}{ Purpose } & Targeted \\
\hline & Non-earmarked \\
\hline \multirow{3}{*}{ Subject } & Key Employees \\
\hline & \begin{tabular}{|l} 
Separate categories of workers \\
\end{tabular} \\
\hline & Seasonal workers in the main place of work \\
\hline \multirow{2}{*}{ Content } & Basic \\
\hline & Additional \\
\hline \multirow{2}{*}{ Obligation } & Mandatory \\
\hline & Not required \\
\hline \multirow{3}{*}{ Payment } & Paid \\
\hline & Partially funded \\
\hline & Without pay \\
\hline \multirow{4}{*}{ Periodicity } & Annual \\
\hline & Training \\
\hline & Vacation \\
\hline & Single \\
\hline \multirow{3}{*}{ Duration } & Minimal \\
\hline & Elongated \\
\hline & Short-term \\
\hline \multirow{2}{*}{ Continuity } & Continuous \\
\hline & Partial \\
\hline \multirow{3}{*}{ Time of granting } & Depending on the season \\
\hline & Depending on the event \\
\hline & Depending on the affiliation \\
\hline \multirow{2}{*}{ Priority } & Regular vacations \\
\hline & Extraordinary vacations \\
\hline
\end{tabular}

Note: suggested on the basis of $[7,20,23]$ and the results of their own research.

Subject to inclusion in official statistical sources, the State Statistics Committee of Ukraine is made public with information on the amount of vacation pay. For example, as part of payments to employees or in addition to the amount of wages paid. The information of the proposed document will allow filling in the articles of the corresponding reporting form.

\section{SWOT analysis of research results}

Strengths. The strength of research is analysis of the specifics of the granting of vacation, on the basis of which the main directions for improving the organizational and 
documentary provision of vacation and its use in the context of social activities of enterprises are outlined.

Weaknesses. The weak side is that information about the specifics of the granting and documenting of vacations, as well as their main types in enterprises and volumes of supply, is not subject to official sources of the State Statistics Committee. Such information is not displayed in the reporting forms of enterprises, which requires the use of additional methods and sources of information collection.

Opportunities. Opportunities for further research are the introduction of the experience of foreign countries to use vacation as one of the methods of motivating employees. The introduction of an internal document into the activities of enterprises, which can have a form that is independent of other documents, and be part of the internal social report of the enterprise. Subject to inclusion in official statistical sources, the State Statistics Committee of Ukraine is made public with information on the amount of vacation pay. For example, as part of payments to employees or in addition to the amount of paid wages. The information of the proposed document will allow filling in the articles of the corresponding reporting form. Fixing information about vacations in the collective agreement of enterprises.

Threats. Threats to the results of conducted research are that modern business conditions of the investigated enterprises are formed more under the influence of external factors than internal ones. The latter affect the features of the formation of their social development strategy, which does not always allow the use of social vacations.

\section{Conclusions}

1. The main historical preconditions and stages of development of the regulatory regulation of the granting of vacation are analyzed. It is determined that each stage is characterized by the improvement of legislation on holidays and the introduction of new types of additional vacation.

2. Such generalized elements are defined as «vacation»: the release of the employee from the performance of labor duties, the retention of the employee in the period of vacation of employment (position), payment. It is established that the term «vacation» is identified with the concept of «time». The main features of the majority of vacations we found as:

- guarantee of vacation by the legislation;

- the scope of the vacations;

- periodicity of granting of vacations;

- determination of the vacation duration in the legis-

lation;

- continuity of rest during the vacation;

- connection of vacation with work experience;

- the main purpose of vacation;

- preservation of the place of work for the vacation period;

- preservation of the average salary for the vacation period;

- vacation payment.

3. The main features of the granting of vacations in agricultural enterprises of the Mykolaiv region are analyzed. They are:

- rather wide differentiation of types of vacations;

- availability of social vacations;
- a widespread phenomenon is the non-reflection of the organizational and documentary mechanism for the registration of vacation in the collective agreement of the enterprise;

- lack of information on the types and volumes of vacation in the reporting forms of enterprises.

4. The main directions of improving the organizational and documentary provision of vacation and its use in the context of the social activities of enterprises are outlined, namely:

- use of vacation as one of the types of employee motivation;

- use of the classification of vacations to improve its planning, analysis and control;

- recording information on vacations in collective agreements of enterprises;

- use of an internal document to display information on the volume of species, sources of coverage for vacation expenses.

\section{References}

1. Otpusk v raznykh stranakh mira. URL: http://www.denga. com.ua/index.php?id=3718\&option $=$ com content\&task $=$ view

2. Mikhaylova M. V chem otlichiya trudovogo zakonodatel'stva raznykh stran. URL: http://www.reccona.com.ua/novosti/123

3. Vacation Leave // United States DEPARTMENT OF LABOR. URL: https://www.dol.gov/general/topic/workhours/vacation leave

4. Harashchenko L. P. Problemy realizatsii prava na vidpustku v Ukraini // Visnyk Akademii pratsi i sotsialnykh vidnosyn Federatsii profspilok Ukrainy. 2012. Vo. 1. P. 30-33.

5. Hutsu S. F. Navchalni ta tvorchi vidpustky za zakonodavstvom Ukrainy // Zbirnyk naukovykh prats KhNADU. Seriia Pravo. 2015. Vol. 5. P. 82-87.

6. Dmytriieva K. I. Pravove rehuliuvannia chasu vidpochynku za zakonodavstvom krain iz rozvynutoiu ekonomikoiu // Chasopys Kyivskoho universytetu prava. 2013. Vol. 1. P. 193-199.

7. Sytnytska O. A. Yurydychni harantii prava na pratsiu ta prava na vidpochynok za trudovym zakonodavstvom Ukrainy: monograph. Khmelnytskyi: Vydavnytstvo Khmelnytskoho universytetu upravlinnia ta prava, 2010. 168 p.

8. Frenkel E. B. Trudovoe i sotsial'noe pravo zarubezhnykh stran. Moscow: Yurist, 2012. 674 p.

9. Suk L. P., Suk P. O. Orhanizatsiia obliku pratsi ta yii oplaty // Bukhhalteriia v silskomu hospodarstvi. 2009. Vol. 21. P. 28-44.

10. Plakhtii T. F., Kalashnyk V. V. Udoskonalennia modeli analitychnoho obliku rozrakhunkiv za vyplatamy // Zbirnyk naukovykh prats Tavriiskoho derzhavnoho ahrotekhnolohichnoho universytetu (ekonomichni nauky). 2013. Vol. 1 (2). P. 239-247

11. Tarca A. Book review: Applying international accounting standards // The International Journal of Accounting. 2007. Vol. 42, No. 1. P. 113-116. doi:10.1016/j.intacc.2006.12.006

12. Dubinina M. V., Kaliahina O. M. Normatyvno-pravove rehuliuvannia ta zabezpechennia obliku rozrakhunkiv z oplaty pratsi na silskohospodarskykh pidpryiemstvakh // Naukovyi visnyk Khersonskoho derzhavnoho universytetu. 2015. Vol. 15 (1). P. 149-152.

13. Tkachenko N. A. Oblikove zabezpechennia skladannia zvitnosti z oplaty pratsi // Ekonomika APK. 2012. Vol. 7. P. 89-94.

14. Koriahin M. V., Popkova O. O. Aspekty zakonodavcho-normatyvnoho rehuliuvannia oplaty pratsi ta yii bukhhalterskoho obliku v krainakh SND // Mizhnarodnyi zbirnyk naukovykh prats. 2011. Vol. 3 (21). P. 204-210.

15. Potryvaieva N. V., Babenko M. D. Perspektyvy udoskonalennia obliku oplaty pratsi v suchasnykh umovakh hopodariuvannia // Visnyk ahrarnoi nauky Prychornomoria. 2008. Vol. 3. P. 31.

16. Syrtseva S. V. Problemy obliku rozrakhunkiv za vyplatamy pratsivnykam v suchasnykh umovakh // Visnyk Prychornomorskoi rehionalnoi naukovo-praktychnoi konferentsii profesorskovykladatskoho skladu. Mykolaiv, 2011. P. 133.

17. Frantsiyan V. F. Problemy zakonodatel'stva ob otpuskakh rabochikh slushhashhikh: abstract's PhD thesis. Moscow, 1973. $22 \mathrm{p}$. 
18. Ostrovskiy L. Ya. Otpuska rabochim sluzhashhim. Minsk: Belarus, 1978. 78 p.

19. Prokopenko V. I. Chas vidpochynku. Kyiv: Politvydav Ukrainy, 1981. $78 \mathrm{p}$.

20. Harashchenko L. P. Pravove rehuliuvannia vidpustok za zakonodavstvom Ukrainy: monograph. Kyiv: Red. haz. «Imenem Zakonu», Pavlim, 2003. 172 p.

21. Cheban Y. Y., Dvornitska T. P., Endres V. S. Vidpustka: teoretychni aspekty // Modern Economics. 2017. Vol. 6. P. 221-228

22. Gintsburg L. Ya. Otpuska robochikh i sluzhashhikh. Moscow: Izd-vo Akademii nauk SSSR, 1961. $162 \mathrm{p}$

23. Pro vidpustky: Law of Ukraine No. 504/96-VR from November 15, 1996 // Baza danykh «Zakonodavstvo Ukrainy». URL http://zakon0.rada.gov.ua/laws/show/504/96-\%D0\%B2\%D1\%80

\section{УСОВЕРШЕНСТВОВАНИЕ ОРГАНИЗАЦИОННО-ДОКУМЕНТАЛЬНОГО} ОБЕСПЕЧЕНИЯ ОТПУСКА

Проведен анализ основных исторических предпосылок и этапов развития нормативного регулирования предоставления отпуска. Исследованы основные особенности предоставления отпуска в сельскохозяйственных предприятиях Николаевской области (Украина). Определены общие элементы составляющих и характеристик понятия «отпуск». Намечены основные направления совершенствования организационно-документаль- ного обеспечения отпуска и его использование в контексте социальной деятельности предприятий.

ключевые слова: регулирование предоставления отпуска, нормативное обеспечение, внутренний документ, коллективный договор, финансовая отчетность.

Dubinina Maryna, Doctor of Economic Sciences, Associate Professor, Department of Accounting and Taxation, Mykolayiv National Agrarian University, Ukraine, e-mail: dubinina@mnau.edu.ua, ORCID: https://orcid.org/0000-0002-3993-0622

Cheban Yuliia, PhD, Associate Professor, Department of Accounting and Taxation, Mykolayiv National Agrarian University, Ukraine, e-mail: gorbachso@mnau.edu.ua, ORCID: https://orcid.org/00000002-8231-2918

Horbach Svitlana, Department of Accounting and Taxation, Mykolayiv National Agrarian University,Ukraine,e-mail:gorbachso@mnau.edu.ua, ORCID: https://orcid.org/0000-0002-0615-8146

Dubinin Viktor, PhD, Associate Professor, Department of Technogenic and Civil Safety, Admiral Makarov National University of Shipbuilding, Mykolayiv, Ukraine, e-mail: Viktor.dubinin@nuos.edu.ua, ORCID: https://orcid.org/0000-0001-9458-5887

Melikhova T. на результати господарської діяльності підприємства. Запропоновані показники економічної ефективності економічної безпеки підприємства побудовані на підставі збільшення виторгу від реалізації продукції, збільшення валової продукиї̈ грошового потоку підприємства та збільшення нагромадженої валової продукції грошового потоку. Обгрунтовано доцільність впровадження системи економічної безпеки та ї̈ поліпшення на підставі запропонованих показників.

Ключові слова: економічна безпека підприємства, чистий та валовий умовний грошовий потік, загальна та порівняльна економічна ефективність.

\section{Introduction}

In modern conditions of eurointegration, the qualitative management of the economic security of an enterprise is one of the main tasks of an enterprise in the course of its economic activities. Economic security affects the increase in the market value of the enterprise, increasing revenues from sales of products, increasing cash flow, reducing losses by improving the reliability of economic security. Achieving these results requires certain costs, but not always the owner own funds to implement such projects. The objective need to investigate innovative and investment projects that can be directed to the implementation of the company's economic security service has determined the relevance and significance of this research.

\section{The object of research and its technological audit}

The object of research is the implementation process of the economic security system in the enterprise and its impact on the results of the economic activity of the enterprise.

The successful operation of the enterprise is based on the implementation of effective economic activity, so the managers are busy with the search for reserves to improve the efficiency of the enterprise. A number of scientists note that the main concern of the manager should be efficiency [1]. And then, under effectiveness, they considered the effectiveness of management and considered it at the macro level with respect to the actions of the government 